\title{
РАСШИРЕННОЕ СОВЕЩАНИЕ
} РУКОВОДИТЕЛЕЙ ПРЕДПРИЯТИЙ РАДИОЭЛЕКТРОННОЙ
ПРОМЫШЛЕННОСТИ:

КУРС НА ДИВЕРСИФИКАЦИЮ

\section{О.Казанцева, Е.Покатаева}

13 апреля 2017 года состоялось традиционное расширенное совещание руководителей предприятий радиоэлектронной промышленности (РЭП). Два ключевых вопроса - о подведении итогов работы отрасли в 2016-м и планах на ближайшие годы - обсуждались в контексте прошедшей накануне Коллегии Минобороны России, на заседании которой шла речь о подготовке проекта Государственной программы вооружения на 2018-2025 годы. Программа, предполагающая техническое переоснащение армии и флота с учетом оценки возможных угроз национальной безопасности России, определит для РЭП новые цели в области создания современных видов вооружений. Наряду с этим остается актуальной задача постепенного перехода организаций оборонно-промышленного комплекса (ОПК) к выпуску высокотехнологичной продукции гражданского назначения.

Президент Владимир Путин в Послании Федеральному собранию 1 декабря 2016 года заявил, что доля гражданской продукции ОПК к 2025 году должна составить 30\%, а к 2030-му - не менее 50\%. О стратегических приоритетах предприятий РэП, перспективах, возможностях и неотложных задачах говорилось на совещании. Приведем выдержки из наиболее интересных выступлений.

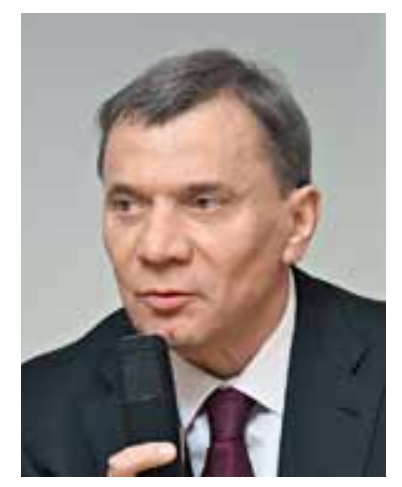

Открылось обсуждение выступлением Юрия Ивановича Борисова, заместителя министра обороны Российской Федерации, он сделал акцент на задачах предприятий радиоэлектронной промышленности, которые предстоит решить в ближайшем будущем. В частности, Юрий Иванович сообщил о реше- ниях Коллегии Минобороны России применительно к комплексу РЭП, обрисовал границы пространства, в котором будет работать отрасль: курс на импортозамещение как важнейший вектор развития, перманентное санкционное давление, негативное влияние мирового финансово-экономического кризиса. Государственная программа вооружения (ГПВ) на 2018-2025 годы разрабатывалась исходя из указанных условий, что нашло отражение в приоритетных направлениях ГПВ: стратегические ядерные силы и высокоточное оружие. По каждому из них ожидается ежегодный рост на уровне 25-30\%. 
Дополнительные приоритеты программы-связь и АСУ. "Работы предстоит много",- подчеркнул Ю.И.Борисов.

Как ожидается, к 1 июня 2017 года ГПВ будет представлена Коллегии Военно-промышленной комиссии, а к 1 июля этого года - Президенту РФ. Сразу после утверждения ГПВ ведомство приступит к заключению контрактов на разработку перспективных образцов военной техники.

Обращаясь к руководителям предприятий РэП, Ю.И.Борисов сказал: "Задача новой ГПВ-свести к минимуму просчеты и ошибки. Ошибки стратегического порядка очень дорого обходятся. В Госпрограмме указан верхний уровень ошибки - менее 5\%. Достижение этого показателя зависит от тесной работы с вами. В этих условиях моя главная задача - обеспечить эффективное взаимодействие между заказчиком в лице оборонной отрасли, главными конструкторами предприятий РЭП, организациями". Свое присутствие на совещании Ю.И.Борисов рассматривал именно с этой точки зрения - как начало углубленного и эффективного взаимодействия ключевого заказчика и предприятий отрасли по пути решения задач, поставленных в новой Госпрограмме вооружения.

\section{Директор Департамента} радиоэлектронной промышленности Минпромторга России Сергей Владимирович Хохлов в докладе "Итоги деятельности радиоэлектронной промышленности за 2016 год. Основные задачи и направления развития промышленности в 2017 году" продолжил тему импортоза-

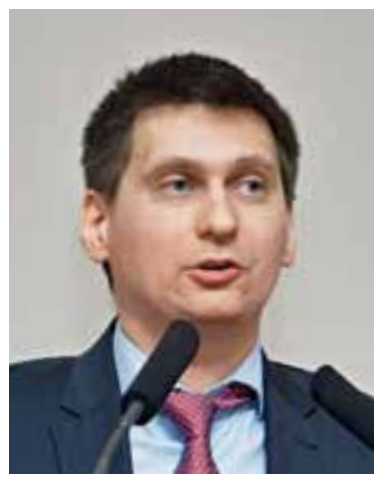
мещения как одного из клю-

чевых направлений прошедшего года, а также подробно остановился на вопросе увеличения выпуска продукции гражданского назначения предприятиями РЭП. В минувшем году отрасль сохранила положительную динамику как в части научно-технических разработок, так и в части производства. По предварительным данным, объем производства промышленной продукции в прошлом году вырос более чем на 22\% (в сопоставимых ценах) до примерно 700 млрд руб.

Серьезнейшим вызовом для отечественной отрасли РЭП С.В.Хохлов назвал ЭКБ для гражданского рынка, на котором, по его оценке, доля зарубежной ЭКБ превышает 80\%. Несмотря на относительно неплохие темпы роста сегмента в 2016 году - 13,7\%, общий объем продукции гражданского назначения составил 57 млрд руб. Радикальное увеличение выпуска гражданской продукции РЭП на основе отечественной ЭКБ-задача, которая может быть решена, как говорится, "всем миром", то есть усилиями различных отраслей.

Минпромторг России связывает большие надежды с увеличением активности отечественных разработчиков конечной радиоэлектронной продукции на базе отечественной ЭКБ в соответствии с Госпрограммой "Развитие электронной и радиоэлектронной промышленности на 2013-2025 годы". Во втором полугодии 2016-го стартовал второй этап программы: по итогам конкурсных отборов господдержка на общую сумму 102 млрд руб. оказывается 102 проектам.

В заключение С.В.Хохлов сформулировал основные задачи отрасли РЭП на 2017 год:

- подготовка предприятий отрасли (в части техники, кадров и т.д.) к выполнению задач Госпрограммы вооружений на 2018-2025 годы;

- усиленное внимание работам по замещению импортноЙ ЭКБ;

- активное развитие гражданских рынков сбыта продукции РЭП в целях достижения соотношения 50 : 50 при активном использовании инструментов стимулирования развития, предложенных государством.

Таким образом, перед отраслью стоят весьма амбициозные задачи. В докладах руководители ведущих предприятий поделились представлениями о возможностях и рисках предстоящей работы.

Алена Владимировна Фомина, генеральный директор АО "ЦниИ "Электроника", отметила: "Перед радиоэлектронной промышленностью, как перед отраслью, исторически ориентированной на производство продукции военного назначения, поставлена задача оперативного перехода организаций оборонно-про-

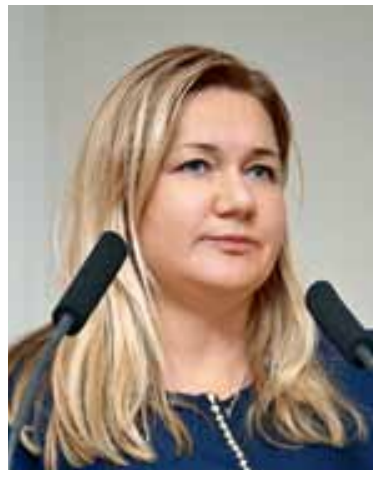
мышленного комплекса к выпуску высокотехнологичной продукции гражданского назначения".

Затем докладчик подробно осветила ход выполнения Госпрограммы по развитию электронной и радиоэлектронной промышленности до 2025 года, которая определяет модель ее развития на долгосрочную перспективу.

Программа, утвержденная 27 апреля 2016 года Постановлением Правительства РФ № 366, предусматривает внедрение принципиально нового подхода к развитию производства гражданской продукции. С весны прошлого года действуют два постановления Правительства РФ, определяющие возможность финансовой поддержки организаций отрасли в реали- 
зации инициативных комплексных проектов на условиях субсидирования.

Во-первых, это субсидия на поддержку комплексных проектов, требующих проведения НИОКР - 50\% всех затрат на эти цели предприятиям возмещаются из бюджета.

Во-вторых, организациям, реализующим комплексные проекты на стадии создания или развития производственной базы, компенсируется часть затрат на выплату процентов по целевым кредитам: субсидируется 2/3 процентной ставки, что удешевляет кредитные ресурсы для предприятий.

Более того, в этом году вводятся субсидии на производство микроэлектронной продукции, то есть организациям компенсируют выпадающие доходы при реализации продукции на российском рынке по конкурентоспособной цене (из следующего расчета: рыночная цена иностранного чипа 14 руб. (0,22 долл. по курсу 65 руб.), себестоимость отечественного чипа65 руб.).

Концепция Госпрограммы включает в себя следующие основные положения.

Первое - ориентация на рынок, с учетом потребностей которого и выпускается серийный продукт гражданского назначения. Комплексный проект предусматривает создание изделия от стадии разработки его концепции до вывода на рынок.

Второе - оптимизация цепочки создания продукта путем включения в кооперацию проекта лучших отраслевых компетенций.

Третье - создание продукции организациями субсидируется на разных стадиях жизненного цикла проектов.

Четвертое - ориентация создаваемого продукта на стратегически значимые и коммерчески эффективные сегменты гражданского рынка. Благодаря развитию таких рыночных ниш возможно достижение установленных целевых показателей и индикаторов отрасли.

В качестве приоритетных направлений были выбраны телекоммуникации, вычислительная техника, системы интеллектуального управления и специальное технологическое оборудование. В рамках подпрограммы по системам интеллектуального управления с 2017 года предусмотрено отдельное мероприятие по развитию микроэлектроники.

Bсе четыре направления показывают высокие темпы роста. При этом рынки телекоммуникационного оборудования, вычислительной техники и систем интеллектуального управления - крупнейшие с точки зрения структуры отечественного рынка - по данным за 2015 год, занимали 45\% общего объема российского рынка профессиональной радиоэлектроники.
Гендиректор АО "ЦНИИ "Электроника" особое внимание уделила субсидиарной политике Департамента РЭП Минпромторга России в рамках Госпрограммы, поскольку она разрабатывалась, в частности, с учетом сложной ситуации, сложившейся на предприятиях отрасли в 2014-2015 годах (см. врезку на с. 26). Однако парадокс заключается в том, что предприятия, которым предназначалась помощь, проявили наименьшую проектную активность - на них приходится 17\% заявок. А 83\% заявок подано частными компаниями, бо́льшая часть которых не принимала участия в ФЦП ЭКБ. Хотя выбор возможностей для предприятий весьма широкий: бюджетное финансирование можно получить как на научные разработки, так и на производство радиоэлектронной и микроэлектронной продукции в рамках комплексного проекта.

Еще большее удивление вызвало отсутствие заявок на получение компенсации процентов по кредитам, привлекаемым на реализацию комплексных проектов. "200 млн государственных средств, предназначенных для облегчения кредитного бремени организаций отрасли, о котором заявляли сами предприятия в 2014-2015 годах, были потеряны для отрасли",констатировала А.В.Фомина. Общая сумма компенсированных средств по 102 комплексным проектам в 2016 году составила 7,6 млрд руб.

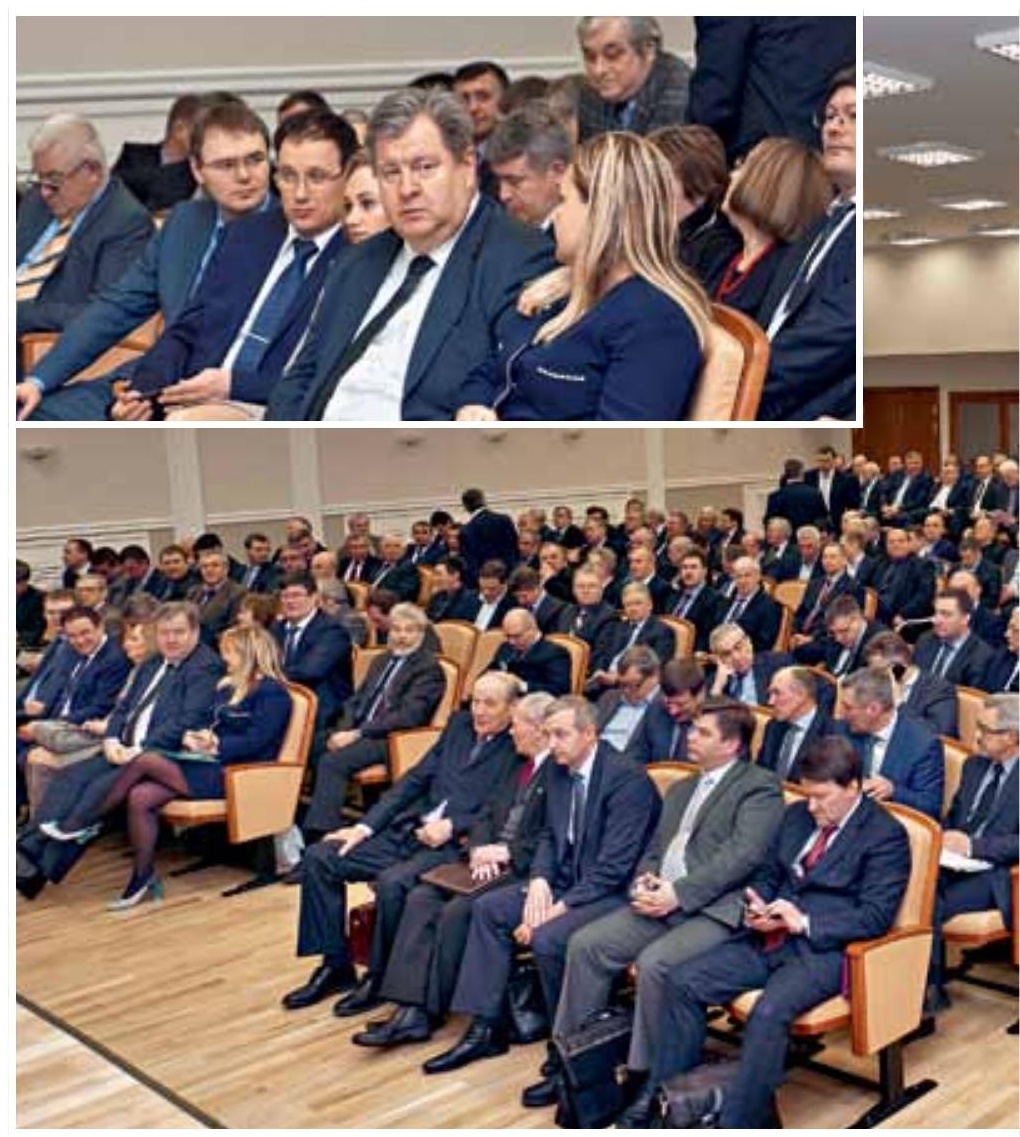


А.В.Фомина привела первые результаты отчетов о реализации проектов, на которые было выделено госфинансирование (согласно Госпрограмме, такие отчеты предприятия должны предоставлять каждые полгода). Период в шесть месяцев, с одной стороны, достаточен для того, чтобы зафиксировать и изучить изменения, произошедшие с проектом за отчетный период, а с другой,- позволяет оперативно принять меры, если обнаруживается расхождение состояния дел и плана-графика реализации проекта. "Первый отчетный период, закончившийся 1 декабря 2016 года, стал для организаций отрасли, участвующих в Госпрограмме, испытанием, с которым они в той или иной степени справились. К сожалению, по состоянию на 1 января 2017 года 55 млн руб., предусмотренных на реализацию отдельных проек-

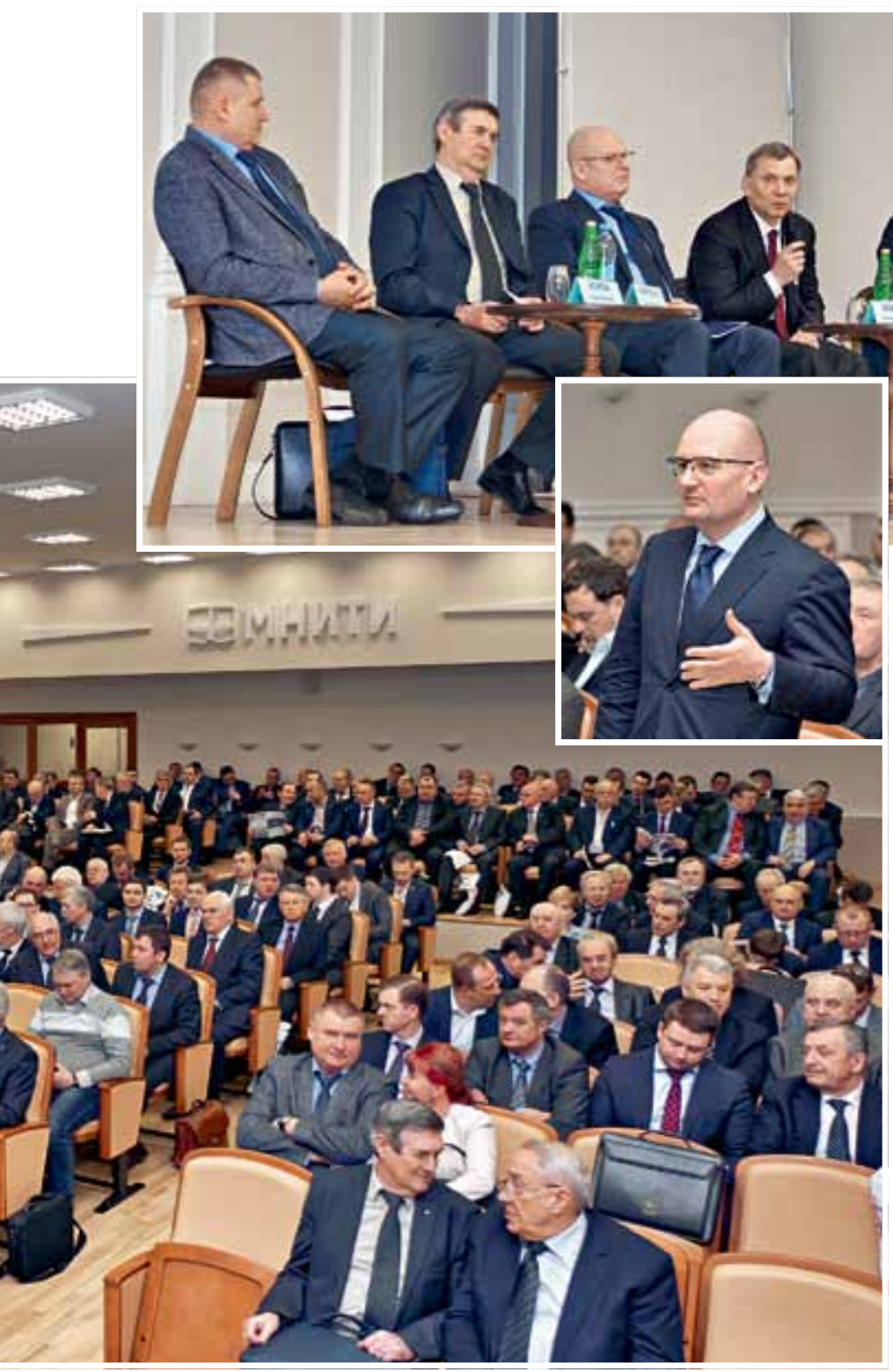

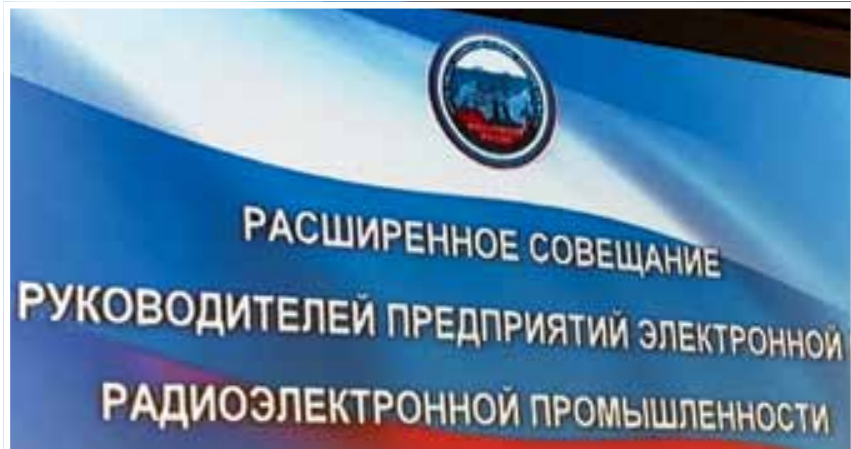
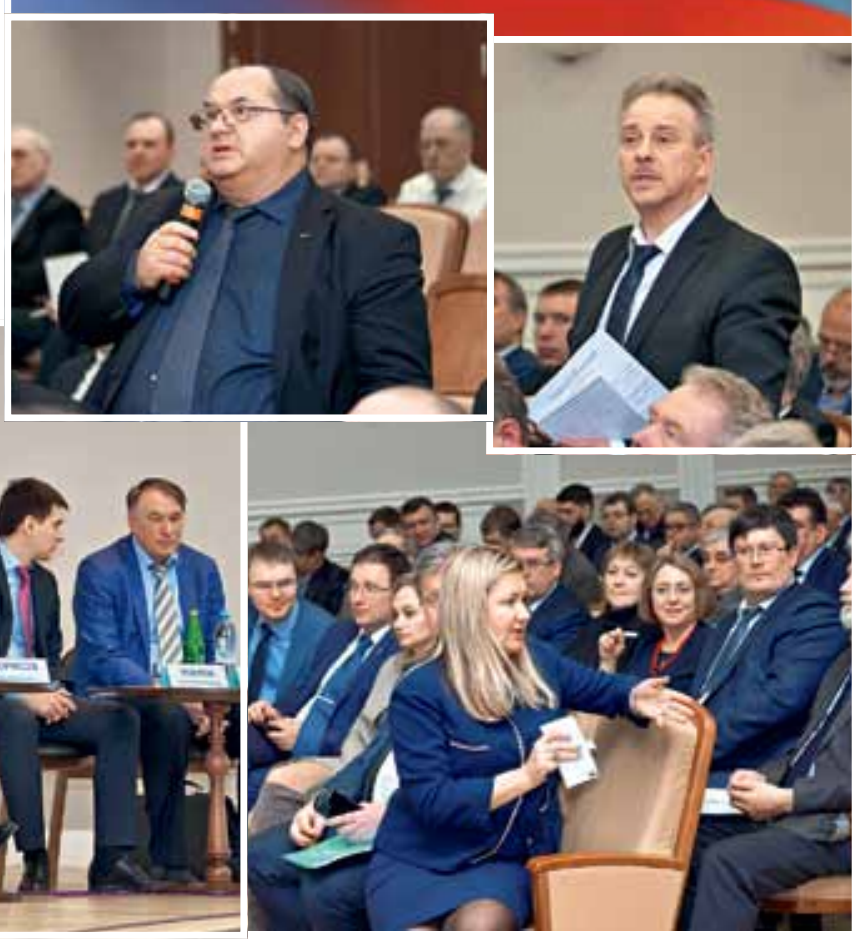

тов, так и не были своевременно выбраны",- сделала вывод А.В.Фомина.

Также с сожалением пришлось признать, что по итогам первого отчетного периода сорван один из ключевых целевых показателей комплексных проектов - объем привлеченного внебюджетного финансирования. Он выполнен организациями только на 63\% относительно плановых значений, установленных договорами организаций с Минпромторгом России. А.В.Фомина указала на ряд недостатков, выявленных в ходе работы с отчетами предприятий:

- неготовность большинства организаций отрасли к оперативному управлению проектами;

- непродуманность взаимоувязки внутреннего порядка ведения учета с нормами и статьями, предусмотренными соответствующим постановлением Правительства РФ;

- несвоевременная подготовка отчетных материалов по комплексным проектам не только организацией, но и соисполнителями; 
- по ряду проектов предоставлялась некорректная отчетная информация либо отчеты содержали технические ошибки.

Выводы по первому отчетному периоду Госпрограммы очевидны: спрашивать с предприятий, которые получают госфинансирование, будут строже, но и самим предприятиям рекомендуется проявлять больше предприимчивости и по максимуму использовать открывающиеся возможноСти.

Новый конкурсный отбор заявок состоится в 2018 году. Соответствующая информация будет размещена на сайте Минпромторга России. К этому времени следует позаботиться о ключевых документах для участия в Госпрограмме: бизнес-плане и финансовой модели комплексных проектов. Правила подготовки данных документов будут опубликованы вместе с конкурсной документацией.

Помимо Госпрограммы организациям отрасли доступен широкий спектр других инструментов поддержки, которые можно условно разделить на три группы в зависимости от характера предоставляемой помощи.

Финансовые меры в виде помощи от Фонда развития промышленности, Внешэкономбанка и фонда Роснано, а также субсидии для системообразующих предприятий отрасли. Также предусмотрены меры поддержки для предприятий оборонно-промышленного комплекса, такие как ФЦП "ОПК".

Регуляторные меры - это специальные инвестиционные контракты, программы инновационного развития, статусы продукции российского происхождения и продукции, не имеющей аналогов, и государственные гарантии.
Еще одна группа мер ориентирована на продвижение деятельности и проектов организации на рынке. Из крупных и функционирующих можно выделить услуги Российского экспортного центра, в рамках которых организации отрасли могут получить полный спектр поддержки - от консультаций и образования в сфере обеспечения экспортных поставок до субсидирования и лицензирования. Поскольку сейчас удачный период для расширения зарубежных поставок, деятельность Российского экспортного центра будет полезна для бо́льшей части организаций отрасли.

Одна из особенностей предприятий отрасли состоит в том, что около 60\% организаций входит в состав Госкорпорации "Ростех". А согласно обновленной стратегии развития этой структуры электроника относится к числу ключевых драйверов развития промышленности.

Цели, которые "Ростех" поставил перед своим электронным кластером, весьма амбициозны: к 2025 году электронный кластер корпорации должен обеспечивать 1,5 трлн руб. выручки (сейчас эта сумма составляет 200 млрд руб.), причем фокус развития направлен на освоение гражданских рынков - их доля в выручке к указанному году должна быть не менее 60\%, то есть 900 млрд руб. При этом, напомнила А.В.Фомина, уровень внедрения в серийное производство результатов разработок, а также загрузки производственной базы, созданных в рамках ФЦП ЭКБ в 2008-2015 годах, очень низкий, а потенциал роста объемов военного рынка существенно ограничен и достигнет своего пикового значения в этом году. "Диверсификацию производства высокотехнологичной продукции нужно развивать уже сегодня", резюмировала А.В.Фомина.

\section{Субсидиарная поддержка в рамках Госпрограммы}

В зависимости от стадии реализации проекта возможно субсидирование научных разработок или производства радиоэлектронной продукции.

\section{Субсидия на НИОКР (ПП РФ от 17.02.16 № 109)}

Компенсация из федерального бюджета до 50\% от общей стоимости НИОКР.

- Участники: 102 проекта, 56 организаций; 17\% - государственные организации, 83\%частные организации.

Финансовое обеспечение (2017-2018 гг.)

2017 год - 9,4 млрд руб., 2018 год - 9,4 млрд руб.
Субсидия на создание производственной базы (ПП РФ от 17.02.16 № 110)

Субсидия на компенсацию части процентов по кредитам, привлеченным исключительно под цели выполнения комплексного проекта.

Лимит субсидии не выбран по причине отсутствия заявок.

Субсидия на производство микроэлектронной продукции (ПП РФ от 23.12.16 № 1450)

Субсидия на компенсацию потерь в доходах, воз никших в 2016-2019 годах в результате производства микроэлектронной продукции, предназна ченной для производства платежных карт.

Cmapm в 2017 20дy. 


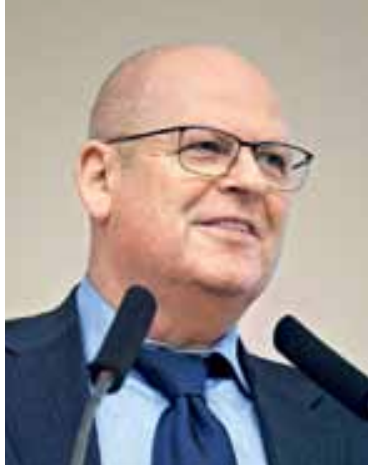

Врио генерального директора АO "Росэлектроника" Григорий Иосифович Элькин начал выступление с разъяснения причин и целей создания крупной отраслевой структуры - Объединенной компании (Росэл и ОПК), так как они, по-видимому, пока далеко не всем понятны: "Цель - органическое развитие объединенной компании на базе существующих оборонных продуктов и компетенций, которые станут заделом для трансфера технологий на гражданских направлениях" (см. врезку на с. 27).

По оценке Г.И.Элькина, одна из существенных причин невысоких темпов развития отрасли отечественной гражданской продукции РЭП заключается в разобщенности проектировщиков конечной продукции (так называемых финишеров) и поставщиков отечественной ЭКБ. "Зачастую финишеры выбирают для своей продукции зарубежную ЭКБ не потому, что она лучше, а потому, что с ее поставщиками проще работать,- пояснил Г.И.Элькин.- И необходимо развивать диалог с российскими поставщиками ЭКБ, чему и будет способствовать структура новой компании".

Результат такой мощной интеграции ожидается нетривиальный. Объединенная компания планирует работать в трех основных сегментах сбыта: госкомпании, крупные коммерческие структуры и розничный рынок. Первый из них, по словам Г.И.Элькина, похож на привычный рынок заказчиков из ВПК, второй - частично известен, благодаря некоторым гражданским проектам, а третий-совсем новый. Заметим, что на этом совещании, пожалуй, впервые прозвучали слова о появлении отечественной персональной электроники. Наша радиоэлектронная отрасль поворачивается лицом к массовому потребителю, что не может не радовать.

Как полагает Г.И.Элькин, объединение "военной" и "гражданской" ипостасей российской электроники позволит повысить эффективность управления работами по Гособоронзаказу (см. врезку на с. 28). Это становится критически важным в то время, когда предприятиям необходимо переходить на отечественную

\section{Направления работ ГК "Ростех" и ОК. Прогнозируемые показатели}

\begin{tabular}{|c|c|c|c|}
\hline $\begin{array}{c}\text { Элементы } \\
\text { Стратегии } \\
\text { гК }\end{array}$ & $\begin{array}{l}\text { Стратегические } \\
\text { цели ГК "Ростех" }\end{array}$ & $\begin{array}{c}\text { Стратегические цели } \\
\text { Кластера }\end{array}$ & Стратегические цели OK \\
\hline $\begin{array}{l}\text { Среднего- } \\
\text { довой рост }\end{array}$ & $\begin{array}{l}\text { 17\%-ный средне- } \\
\text { годовой рост } \\
\text { в рублях }{ }^{1}\end{array}$ & 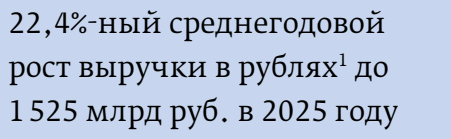 & 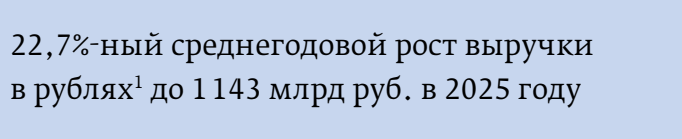 \\
\hline $\begin{array}{l}\text { Рынки: } \\
\text { от "железа" } \\
\text { к "интел- } \\
\text { лекту" }\end{array}$ & $\begin{array}{l}\text { Доля гражданской } \\
\text { продукции 50\% } \\
\text { в } 2025 \text { году } \\
\text { Рост доли экспорта }\end{array}$ & $\begin{array}{l}\text { Доля гражданской продук- } \\
\text { ции } \approx 60-70 \% \text { в } 2025 \text { году. } \\
\text { Ключевые гражданские сег- } \\
\text { менты: передача и хранение } \\
\text { данных, фотоника и ЭКБ, } \\
\text { безопасность, медтехника, } \\
\text { оптика }\end{array}$ & $\begin{array}{l}\text { Доля гражданской продукции ₹66\% в } 2025 \\
\text { году. } \\
\text { Акцент развития: оборудование и решения } \\
\text { в области связи и передачи данных, интел- } \\
\text { лектуальных систем безопасности АСУ, робо- } \\
\text { тотехники, ЭКБ и материалов }\end{array}$ \\
\hline $\begin{array}{l}\text { Партнер- } \\
\text { ства }\end{array}$ & $\begin{array}{l}\text { Привлечение } \\
\text { "умного" капитала }\end{array}$ & $\begin{array}{l}\text { Перераспределение активов } \\
\text { в продуктовые группы для } \\
\text { привлечения частного капи- } \\
\text { тала и финансирования } \\
\text { инвестиций }\end{array}$ & $\begin{array}{l}\text { Создание условий для сотрудничества с раз- } \\
\text { работчиками значимых продуктов } \\
\text { Взаимодействие с фондами для привлечения } \\
\text { инвестиций } \\
\text { Создание партнерств и альянсов в целях } \\
\text { разработки/трансфера технологий, получе- } \\
\text { ния доступа к глобальным и региональным } \\
\text { рынкам }\end{array}$ \\
\hline
\end{tabular}

1 Темпы роста ГК "Ростех" приведены за 2014-2025 годы, остальные - за 2015-2025 годы. 
ЭКБ и одновременно расширять номенклатуру за счет гражданской продукции. Объединенная компания собирается использовать для решения таких сложных комплексных задач структуру проектных офисов, специализирующихся на разных типах продукции (ЭКБ, СВЧ, радиолокация, разработка и внедрение АСУ, проектирование и производство средств связи), и процессный метод управления проектами.

Еще одно нововведение коснется АО "Росэлектроника". "Мы привыкли работать в рамках гособоронзаказа на одного заказчика,- говорит Г.И.Элькин.- На открытом рынке так действовать нельзя, у нас будут созданы отделы маркетинга и прочие структуры, необходимые для продвижения продукции на открытом коммерческом рынке". Это становится критически важным для сегмента крупных предприятий, а для розничного рынка - жизненно необходимым элементом деятельности. "Приступая к работе на розничном рынке, нужно понимать, во-первых, в какие сегменты мы идем и, во-вторых, как будем организовывать сбыт своей продукции",- пояснил Г.И.Элькин. В части сбыта, уверен докладчик, необходимо обращать внимание на зарубежный опыт, подтверждающий необходимость лоббирования сбыта определенных технических решений со стороны государства. С этой точки зрения несложно произвести, скажем, "умные" датчики для ЖКХ, значительно труднее стимулировать их сбыт всем предприятиям ЖКХ в стране. Однако инициативу в данном вопросе (сбыт продукции), подчеркнул Г.И.Элькин, должны проявить именно предприятия, производящие ЭКБ и конечные изделия, только потом ее поддержит государство.

Ожидаемые темпы роста объединенной компании на уровне отрасли, даже чуть выше -22,4\%. Г.И.Элькин отметил, что заданные темпы развития будут обеспечиваться благодаря органическому развитию предприятий и инвестиционной господдержки, направляемой на приобретение новых бизнесов, в частности начинающих технологических компаний (стартапов).

Тему потенциальных рисков крупных комплексных проектов развил Сергей Иванович Боков, начальник ФГБУ"46 нИИ" Минобороны России в докладе "Проект формирования государственной программы вооружения". По его словам, общее стратегическое видение перспектив разработки новых изде-

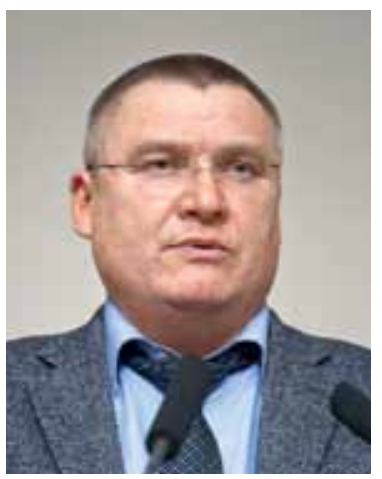
лий должно подкрепляться

единой базой требований, которые позволят обеспечить согласованность между отдельными элементами новой ГПВ и взаимопонимание ее участников. При этом сбалансированность и координация госпрограмм представляют собой большую проблему. Они должны быть

\section{Направления развития ОК на базе оборонных продуктов и компетенций для трансфера технологий на гражданских направлениях}

\section{Связь и передача данных}

- Устройства радиосвязи, приемное и передающее оборудование.

- мобильные комплексы связи, обслуживания и ремонта аппаратуры.

- Периферийная аппаратура.

- Телекоммуникационное оборудование.

\section{СВЧ и ЭКБ}

- Радиационно-стойкая ЭКБ, пассивная ЭКБ.

- Полупроводниковые светодиоды, светильники.

- Химические источники тока, накопители, преобразователи.

\section{ACY}

- Системы управления, мониторинга и визуализации тактической обстановки.
- АСУ ВС РФ, видов и родов войск, военных округов, армий.

- Вычислительная техника.

- Информационно-техническая защита.

- Робототехнические комплексы.

РЭР, РЭБ

- Системы и средства радиоэлектронного противоборства, радиопеленгации и перехвата.

- Системы технического зрения, средства сбора и отображения информации, тепловизионные приборы, опто-фотоэлектронные приборы.

\section{КИП, мед. техника}

- Измерительные средства в интересах Метеорологической службы.

- Техника в области магнитотерапии, аэроинотерапии, стимуляции биоритма. 
четко скоординированы в части формирования научнотехнического задела и проектирования перспективных образцов продукции на базе научно-технического задела. Фактически, полагает С.И.Боков, речь идет о создании мощной вертикали определения и установки требований к перспективным образцам продукции, что само по себе является серьезной задачей, начиная от структуры и заканчивая регламентами координации. Институт собирается представить на заседании Коллегии Минобороны РФ в мае вариант решения этой задачи. По словам С.И.Бокова, речь идет о компьютерной аналитической системе, которая объединила в рамках общего информационного пространства деятельность 22 главных конструкторов, 14 генеральных технологов, 5000 номенклатурных элементов вооружений и многие тысячи элементов ЭКБ. Совокупность этих данных позволяет проводить анализ по огромному количеству разрезов (можно получить миллионы разнообразных отчетных таблиц). Возможности системы позволяют выполнять сложные аналитические действия типа "что, если...". По мнению С.И.Бокова, аналитический инструментарий такого уровня должен быть в распоряжении каждого предприятия: "Для экономики предприятия архиважен вопрос, как оно будет жить завтра? А как оно может сегодня дать ответ на такой вопрос, если за пределами гособоронзаказа пока все достаточно туманно?" Аналитические системы позволят моделировать варианты консолидации с гражданским сектором и просчитывать потенциальные результаты бизнеса через пять, десять лет.

В докладе "Основные результаты работ по созданию и перспективы развития отечественной электронной компонентной базы оборонного назначения", с которым выступил директор ФГУП "МНИИРИП" Виктор Валентинович Алексеев, проблемы стратегического управления научно-техни-

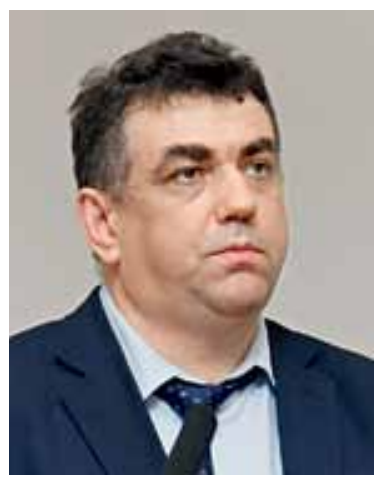
ческими разработками рассматривались применительно к ЭКБ оборонного назначения. Докладчик отметил масштабность работ. Так, по трем направлениям - создание ЭКБ, замещение ЭКБ, производимой на Украине, замещение ЭКБ с производством в странах НАТО и ЕС-одновременно выполняются сотни проектов. Из них только украинское направление, охватывающее наиболее узкий спектр продукции, насчитывает почти две сотни типов ЭКБ. Здесь работы близки к завершению, тогда как активность импортозамещения ЭКБ из стран НАТО и ЕС будет только нарас- тать. В частности, запланированы существенные изменения в сфере силовой электроники (более 260 типов ЭКБ). На решение этих задач выделяется наиболее крупная сумма госфинансирования. Несколько меньше-на создание отечественной ЭКБ.

При таких масштабах разработок, производства и с учетом поставленной задачи в 95\% отечественной продукции в составе системообразующей ЭКБ, подчеркнул В.В.Алексеев, проблемой становится отсутствие четких ориентиров в сфере разработки изделий. В частности, целесообразно закреплять за каждым изделием отвечающего за него генерального конструктора. Докладчик обратил внимание присутствующих на то, что понятие обеспеченности системообразующей ЭКБ отечественной продукции не тождественно понятию применимости.

Для того чтобы привести процессы разработки ЭКБ в систему, специалисты ФГУп "МНИИРИП" разработали сбалансированную концепцию формирования минимально функционального набора ЭКБ на основе дерева классификаций.

Свой вклад в обсуждение проблем эффективного управления масштабными процессами научно-технических разработок внес Борис Николаевич Авдонин, советник директора ФГУП "МНИИРИП", который рассказал о возобновлении активной работы Научнотехнического совета отрасли,

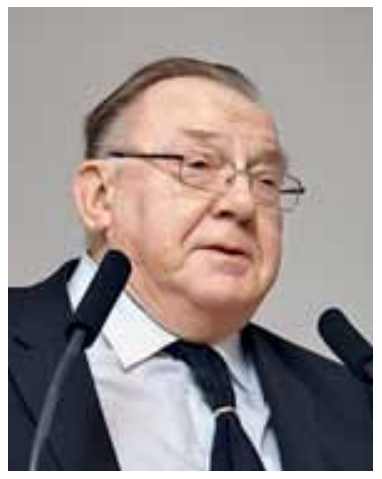
некоторое время назад фактически прекратившего свою деятельность. Докладчик обратил внимание на целевой показатель ежегодного роста отрасли-22\%. "Достичь таких значений можно, если вести планомерную работу со всеми отраслями, где будут внедряться изделия предприятий,-уверен эксперт.-НТС может стать объединяющей площадкой, на которой предприятия из разных отраслей смогут общаться и вместе решать возникающие вопросы". Задачи отрасли настолько масштабны, что интеграционные процессы должны пронизывать все сообщества: Совет главных конструкторов, Научно-технический совет и т.д.

$$
\because ;
$$

Подводя итог обсуждению, С.В.Хохлов охарактеризовал нынешний 2017 год как важную веху в развитии отрасли - начало "жизни" в рамках новой ГВП под флагом движения отрасли в сторону гражданской продукции. "Работать на различных гражданских рынках непросто. Но по-другому нельзя. Нужно учиться",сделал вывод С.В.Хохлов. 